http://dx.doi.org/10.1590/1678-4162-9260

Arq. Bras. Med. Vet. Zootec., v.69, n.4, p.843-850, 2017

\title{
Characterization of virulence and antibiotic profile and agr typing of Staphylococcus aureus from milk of subclinical mastitis bovine in State of Rio de Janeiro
}

\author{
[Caracterização do perfil de virulência e resistência antimicrobiana e tipagem agr de Staphylococcus aureus \\ oriundos do leite bovino de mastite subclinica no estado do Rio de Janeiro] \\ B.S. Soares, D.A. Melo, C. C. Motta, V.F. Marques, N.B. Barreto, \\ S.M.O. Coelho, I.S. Coelho, M.M.S. Souza \\ Universidade Federal Rural do Rio de Janeiro - Seropédica, RJ
}

\begin{abstract}
This study aims to detect the main virulence and antimicrobial resistance genes in Stapylococcus aureus from bovine mastitic milk as well as classifying them according to agr typing. A total of 55 strains from six dairy unities in the state of Rio de Janeiro were selected, of these $27.3 \%$ presented $f b n A$ and $78,2 \%$ for $f b n \mathrm{~B}$ genes, respectively. None of the strains tested were positive for cap5 gene, $3.6 \%$ were positive for cap 8 gene. Additionally, $94.5 \%$ of strains had hlA gene and $89.1 \%$ had $h l B$ gene while $67.3 \%$ of the strains had icaA gene and $87.3 \%$ had icaD gene. From these results it was possible to establish 12 different virulence profiles. Prevalence of agrII type was detected in $81.8 \%$ of the isolates. Concerning antimicrobial resistance evaluation, the studied strains were susceptible to all antibiotics tested except penicillin, $83.6 \%$ being resistant strains. None of the strains had mecA gene, however, $40 \%$ of the strains had blaZ gene. Associating virulence and resistance data made it possible to obtain 23 different profiles. This great diversity of strains shows wide array of bacterial strategies and the challenge of mastitis prevention in cattle. Despite antimicrobial susceptibility, these strains presented certain genes that allow its persistence in the herd.
\end{abstract}

Keywords: agr typing; antibiotics; bovine mastits; Staphylococcus aureus; virulence

\section{RESUMO}

O presente estudo teve como objetivo detectar os principais genes de virulência e resistência antimicrobiana em Staphylococcus aureus oriundos de leite bovino mastítico e classificá-los de acordo com a tipagem do gene agr. Foram selecionados 55 isolados de seis unidades produtores no estado do Rio de Janeiro. Destas, o gene fbnA foi encontrado em $27,3 \%$ das cepas e 78,2\% possuíam o gene fbnB. Em nenhuma cepa foi encontrado o gene cap5 e 3,6\% possuíam o gene cap8. O gene hlA foi encontrado em $94,5 \%$ das cepas e $89,1 \%$ possuíam o gene hlB. O gene icaA foi encontrado em $67,3 \%$ das cepas $e$ 87,3\% possuíam o gene icaD. Com base nesses resultados, foi possível estabelecer 12 diferentes perfis de virulência. Prevalência do agr tipo II foi detectada em $81,8 \%$ dos isolados. Considerando-se a avaliação da resistência antimicrobiana, as cepas estudadas foram suscetíveis a todos os antibióticos exceto penicilina, sendo detectado um percentual de 83,6\% de cepas resistentes. Nenhuma das cepas apresentou o gene mecA, contudo 40\% das cepas apresentaram o gene blaZ. Vinte e três perfis diferentes foram estabelecidos por associação de dados de virulência e resistência. Essa grande diversidade de cepas mostra a ampla gama de estratégias bacterianas e o desafio da prevenção à mastite no gado bovino, considerando-se que, a despeito da suscetibilidade antimicrobiana, essas cepas apresentam genes que permitem sua persistência no rebanho.

Palavras-chave: antibióticos, mastite bovina, Staphylococcus aureus, tipagem agr, virulência

Recebido em 7 de outubro de 2016

Aceito em 10 de outubro de 2016

E-mail: biancadssoares@gmail.com 


\section{INTRODUCTION}

Milk production is considered one of the main agricultural activities in Brazil (Rigolin-Sá et al., 2014). Mastitis is recognized as the main cause of economic losses in dairy industry due to reduced milk production in cows, increased expenditure due to treatment of cows and losses associated with withdrawal and disposal of affected milk during the infection period (Reshi et al., 2015). In addition, mastitis represents a potential risk to consumer health through transmission of zoonotic agents, possibility of triggering allergies, changes in the balance of intestinal microbiota and selection of resistant bacteria in digestive tract from the use of antibiotics (Cassol et al., 2010).

Although several bacterial pathogens can cause mastitis, Staphylococcus aureus is one of prevalent etiologic agents of this disease in dairy cattle worldwide. Furthermore, cases of mastitis are often subclinical and difficult to treat (Wang et al., 2015). Indiscriminate use of antimicrobials to combat mastitis has led to selection of resistant strains of Staphylococcus spp., undermining the efficacy of treatment. Betalactam antibiotics are routinely used to treat intramammary infections (Haveri et al., 2008). Limited success of antibiotic therapy may also be due to the ability of $S$. aureus to invade and survive within different cell types found in the mammary gland including phagocytes such as fibroblasts, osteoblasts, and various epithelial cell types (Bur et al., 2013).

In addition to resistance, pathogenicity of Staphylococcus associated with mastitis is an extremely important feature in the disease process that requires a better understanding. Ability of $S$. aureus to cause various infections and intoxication, results from the production of different virulence factors (Aung et al., 2011; Capurro et al., 2010). The capsule production increases microbial virulence of bacteria becoming resistant to phagocytosis and the serotypes 5 also 8 are prevalent in human and animal infections (Tuchscherr et al., 2005). The S.aureus infection can also be facilitated by fibronectin production which helps its adhesion to epithelial cells and glandular epithelium facilitating the dispersion in the host (El-Sayed et al., 2006). In addition, slime production is considered a virulence factor that inhibits the immune response of the host and facilitates the adhesion of the pathogen (Atkin et al., 2014). Finally, the $\alpha$ - and $\beta$-hemolysins are the most important virulent factors in the pathogenesis of bovine mastitis. They are pore-forming exotoxins that induce proinflammatory changes in mammalian cells, inactivate the immune system by their direct cytotoxic effect, and degrade tissues, providing bacteria with nutrients and facilitating spreading to new sites. The $\alpha$ and $\beta$ hemolysin are encoded by $h l \mathrm{~A}$ and $h l \mathrm{~B}$, respectively, and both genes are controlled by gene regulatory accessory agr (Bownik and Swicki, 2008).

The accessory gene regulator (agr) can regulate the expression of cell surface proteins and extracellular virulence factors (Moodley et al., 2006). agr (accessory gene regulator) locus is a quorum-sensing system that controls expression of a variety of genes involved in tissue colonization (e.g., surface proteins) and invasion (e.g., extracellular toxins). agr system is polymorphic and permits classification of $S$. aureus strains in four groups (Buzzola et al., 2007). Due to the considerable impact on milk production caused by the persistence of $S$. aureus in herds, the knowledge of the molecular profile of strains allows epidemiological studies of dispersion of this pathogen in rural properties, resulting in the elucidation of the mechanism of pathogenesis. Therefore, strategies and protocols prophylaxis and control of mastitis can be better assembled.

This study aims to characterize $S$. aureus isolated from cases of subclinical bovine mastitis in the State of Rio de Janeiro in order to establish virulence and resistance profiles as well as to classify agr typing.

\section{MATERIALS AND METHODS}

Six dairy cattle farms located in an important milk production region of Rio de Janeiro State, Brazil, were selected due to its high prevalence of subclinical mastitis through the California Mastitis Test (CMT) and Somatic Cell Count (SCC). A total of 512 milk samples were collected from October and November 2012. A total of 291 Staphylococcus spp. was isolated, among which 128 were $S$. aureus. After antimicrobial susceptibility test results, a representative strain from each of 55 antibiotype groups was randomly selected. The Veterinary Institute Animal Care and Use Committee 
(protocol number, CEUA 3664040915) certified this study.

Bacterial total DNA extraction was performed according to the protocol established by LABACVET as follows: a $1.5 \mathrm{~mL}$ overnight culture was prepared by inoculation of a single colony of $S$. aureus into broth and incubated at $37 \mathrm{C}$. Broth was centrifuged (three times) and the cell pellet re-suspended in $600 \mu \mathrm{L}$ of lysis solution $(200 \mathrm{mM}$ TrisHCl, $25 \mathrm{mM}$ EDTA, 25 $\mathrm{mM} \mathrm{NaCl}, 1 \%$ SDS, $\mathrm{pH} 8.0$ ) and heated to $65^{\circ} \mathrm{C}$ for $30 \mathrm{~min}$. DNA was extracted with chloroform: isoamyl alcohol 25:24:1 twice and precipitated by 2 volumes of ice-cold ethanol. DNA pellet obtained was washed with $70 \%$ ethanol and re-suspended in $30 \mu \mathrm{L}$ of TE buffer $(10 \mathrm{mM}$ Tris-HCl, 1mM EDTA, pH8.0) and stored at $-20^{\circ} \mathrm{C}$ until use.

Genotypic characterization of $S$. aureus was performed by amplification of coagulase (coa) (Hookey et al., 1998) and species specific (nuc) (Ciftci et al., 2009) genes. The analysis of virulence factors comprised the detection of the following genes: icaA and icaD (Vasudevan et al., 2003) implicated in the production of slime; fnbA and fnbB that codifies fibronectin binding proteins; cap5 and cap 8 related to the expression of capsule (El-Sayed et al., 2006) and the hemolysin genes hlA and hlB (Nilsson et al., 1999). ATCC 29213 S. aureus was used as quality control. PCR products were separated by electrophoresis on $1 \%$ agarose gels, which were revealed with SYBR Green (Invitrogen $($ ) diluted dye (1:100), enabling the visualization and documentation of amplicons by the image capturing system L-PIX EX (Loccus Biotecnologia () .

Classification of agr system groups was based on the hyper variable domain of agr locus according to Shopsin et al. (2003). Duplex PCR was performed to type groups based on their products size. PCR products were separated by electrophoresis on $1 \%$ agarose gels which were stained with a 1:100 dilution of SYBR Green (Invitrogen $\AA$ ), enabling the visualization and documentation of amplicons by the image capturing system L-PIX EX (Loccus Biotecnologia $\left.{ }^{\circledR}\right)$.

Phenotypic resistance detection were performed according to Clinical and Laboratory Standards
Institute veterinary guidelines to the following antimicrobials: cefoxitin $(30 \mu \mathrm{g})$, oxacillin $(10 \mu \mathrm{g})$, penicillin (10IU), amoxicillin + clavulanic acid $(30 \mu \mathrm{g})$, and erythromycin $(15 \mu \mathrm{g})$ (CLSI VET01-A4, 2013). Standard strains S. aureus ATCC 43300 and S. aureus ATCC 29213 were used as quality control. For the genotipic characterization of beta-lactamic resistance, mecA (Murakami et al., 1991) and blaZ (Rosato et al., 2003) genes were amplified and PCR products were separated by electrophoresis on $1 \%$ agarose gels, stained with a 1:100 dilution of SYBR Green (Invitrogen $\AA$ ), enabling the visualization and documentation of amplicons by the image capturing system L-PIX EX (Loccus Biotecnologia $\left.{ }^{\circledR}\right)$.

\section{RESULTS}

All strains were genotypically confirmed as $S$. aureus. They generated variable sized fragments compatible with those expected for coa gene and fragments of $279 \mathrm{bp}$ compatible with presence of nuc gene confirming their identification as $S$. aureus.

Regarding virulence factors analysis, a total of $27.3 \%(15 / 55)$ were positive for $f b n \mathrm{~A}$ gene and $78.2 \%(43 / 55)$ for $f b n B$ gene, genes implicated in fibronectin production. The cap 8 was detected in two strains whereas the unusual cap5 gene was not found in any strain. Genes associated to hemolysin production were found in $94.5 \%(52 / 55-h l A)$ and $89.1 \%(49 / 55-h l B)$, respectively. The slime production associated ica $\mathrm{A}$ and icaD genes were detected in $67.3 \%$ $(37 / 55)$ and $87.3 \% \quad(48 / 55)$, respectively (Table 1).

Table 1. Prevalence of virulence associated genes in $S$. aureus associated with mastitis in cattle

\begin{tabular}{lcc}
\hline \multicolumn{1}{c}{ Function } & Genes & Prevalence \\
\hline Hemolysin production & hlA & $94.5 \%(52 / 55)$ \\
& hlB & $89.1 \%(49 / 55)$ \\
Slime Production & icaA & $67.5 \%(37 / 55)$ \\
& icaD & $87.3 \%(48 / 55)$ \\
Fibronectin & fbnA & $27.3 \%(15 / 55)$ \\
Capsule & fbnB & $78.2 \%(43 / 55)$ \\
& cap5 & $0 \%(0 / 55)$ \\
& & \\
& cap8 & $4.4 \%(2 / 55)$ \\
\hline
\end{tabular}


Genetic analysis of virulence yielded a total of 14 different profiles. Profile 11 was found to be the most prevalent, detected in $43.6 \%(24 / 55)$ of strains, followed by profile 12 observed in $12.7 \%$ (7/55) (Table 2).

Through the analysis of the virulence genes implicated in the pathogenesis of mastitis it was possible to observe that they are widely distributed among studied strains confirming their high potential for causing this disease. Most strains $81.8 \%(45 / 55)$ were classified as agr type II and $18.2 \%(10 / 55)$ strains could not be classified in any agr type. Also, the prevalent profile 11 was found in strains from all analyzed farms demonstrating its ample dissemination in the studied region. Most strains (22/24) belonging to this profile were typified as agr group II; however, two strains were not typeable.

Table 2. Distribution of virulence gene profiles among the studied Staphylococcus aureus strains

\begin{tabular}{|c|c|c|c|c|}
\hline Profiles & Genes & Farms & agr Typing & Prevalence \\
\hline 1 & $h l \mathrm{~A}$, hlB, icaA and icaD & $\mathrm{E}$ & II & $3,6(2 / 55)$ \\
\hline 2 & $f b n \mathrm{~A}, f b n \mathrm{~B}, h l \mathrm{~A}, h l \mathrm{~B}, i c a \mathrm{~A}$ and icaD & $\mathrm{D}$ & II & $9,1(5 / 55)$ \\
\hline 3 & $f b n \mathrm{~B}, h l \mathrm{~A}, h l \mathrm{~B}, i c a \mathrm{~A}$ and icaD & $\mathrm{D} ; \mathrm{E}$ & NT; II & $5,6(3 / 55)$ \\
\hline 4 & $f b n \mathrm{~B}, h l \mathrm{~A}, h l \mathrm{~B}$ and $i c a \mathrm{D}$ & $\mathrm{D}$ & NT; II & $3,6(2 / 55)$ \\
\hline 5 & $f b n \mathrm{~B}$ and $i c a \mathrm{D}$ & $\mathrm{D}$ & II & $1,8(1 / 55)$ \\
\hline 6 & $f b n \mathrm{~A}, f b n \mathrm{~B}, h l \mathrm{~A}, h l \mathrm{~B}$ and $i c a \mathrm{D}$ & $\mathrm{C}$ & II & $1,8(1 / 55)$ \\
\hline 7 & $f b n \mathrm{~A}, f b n \mathrm{~B}, h l \mathrm{~A}$ and icaD & $\mathrm{E}$ & II & $1,8(1 / 55)$ \\
\hline 8 & $f b n \mathrm{~A}, f b n \mathrm{~B}$ and icaA & $\mathrm{D}$ & II & $1,8(1 / 55)$ \\
\hline 9 & $f b n B$ & A & NT & $1,8(1 / 55)$ \\
\hline 10 & $f b n \mathrm{~A}, c a p 8, h l \mathrm{~A}, h l \mathrm{~B}$ and $i c a \mathrm{~A}$ & $\mathrm{C} ; \mathrm{F}$ & II & $3,6(2 / 55)$ \\
\hline 11 & $f b n \mathrm{~A}, h l \mathrm{~A}, h l \mathrm{~B}, i c a \mathrm{~A}$ and $i c a \mathrm{D}$ & $\mathrm{A} ; \mathrm{B} ; \mathrm{C} ; \mathrm{D} ; \mathrm{E} ; \mathrm{F}$ & NT; II & $43,6(24 / 55)$ \\
\hline 12 & $f b n \mathrm{~A}, h l \mathrm{~A}, h l \mathrm{~B}$ and $i c a \mathrm{D}$ & $\mathrm{C} ; \mathrm{D} ; \mathrm{E}$ & NT; II & $12,7(7 / 55)$ \\
\hline 13 & $h l \mathrm{~A}$ and $h l \mathrm{~B}$ & $\mathrm{~A} ; \mathrm{B}$ & NT; II & $5,6(3 / 55)$ \\
\hline 14 & $f b n \mathrm{~A}, h l \mathrm{~A}$ and $i c a \mathrm{D}$ & $\mathrm{D} ; \mathrm{E}$ & NT; II & $3,6(2 / 55)$ \\
\hline
\end{tabular}

Regarding antimicrobial resistance assays all strains were susceptible to the tested antibiotics with exception of penicillin $(83.6 \%$ - 46/55). None isolate tested positive to mecA gene and $40 \%(22 / 55)$ were positive for blaZ gene.

Through clustering data virulence and resistance, it was possible to obtain 23 different profiles. Profile 12 was the prevalent profile $(23.6 \%$ - 13/55) and it was distributed in 3 different farms (Table 3 ).

\section{DISCUSSION}

Mastitis caused by S. aureus is the result of the production of a large array of virulence factors that may contribute to its pathogenesis in different ways. Virulence factors of S. aureus allow the bacteria to attach, colonize and invade the host. In this study, the presence of virulence genes related to several steps of bovine mastitis pathogenesis was investigated.
The ability of $S$. aureus to produce biofilm is considered important as a virulence determinant in pathogenesis of mastitis. Biofilm helps in adhesion and colonization of organism in the epithelium of mammary gland and also increases antibiotic resistance. Involvement of biofilm infections has led to increased interest in characterizing genes involved in biofilm formation. In this study, most $S$. aureus strains presented the genetic ability to produce biofilm since the slime production associated icaA and icaD genes were detected in $67.3 \%(37 / 55)$ and $87.3 \%$ (48/55), respectively. In Belgium, Ote et al. (2011) detected $86.9 \%$ icaA and $95 \%$ icaB positive $S$. aureus strains in a 229 bovine mastitis sampling corroborating the present data of high prevalence of these genes in dairy environment. Presence of at least one of genes has been detected in most isolates of $S$. aureus bovine mastitis demonstrating its importance as virulence factors in the pathogenesis of bovine mastitis (Atkin et al., 2014). 
Table 3. Distribution of virulence and resistance genes and antibiotype among the studied Staphylococcus aureus strains

\begin{tabular}{|c|c|c|}
\hline Virulence and resistance genes and antibiotype profile & Profile & Prevalence \\
\hline$f b n \mathrm{~A}, f b n \mathrm{~B}, h l \mathrm{~A}, h \mathrm{~B}, i c a \mathrm{~A}, i c a \mathrm{D}, \mathrm{PEN}(\mathrm{R}), \mathrm{AMC}(\mathrm{S}), \mathrm{CFO}(\mathrm{S}), \mathrm{OXA}(\mathrm{S})$ and ERI(S) & 1 & $9 \%(5 / 55)$ \\
\hline$f b n A, f b n B, h l \mathrm{~A}, h l \mathrm{~B}, i c a \mathrm{D}, \mathrm{PEN}(\mathrm{S}), \mathrm{AMC}(\mathrm{S}), \mathrm{CFO}(\mathrm{S}), \mathrm{OXA}(\mathrm{S}), \mathrm{ERI}(\mathrm{S})$ and blaZ & 2 & $1,8 \%(1 / 55)$ \\
\hline$f b n A, f b n B, h l \mathrm{~A}, i c a \mathrm{D}, \mathrm{PEN}(\mathrm{R}), \mathrm{AMC}(\mathrm{S}), \mathrm{CFO}(\mathrm{S}), \mathrm{OXA}(\mathrm{S})$ and ERI(S) & 3 & $1,8 \%(1 / 55)$ \\
\hline$f b n A, f b n B, i c a A$, PEN (R), AMC (S), CFO (S), OXA (S) and ERI(S) & 4 & $1,8 \%(1 / 55)$ \\
\hline$f b n B, h l \mathrm{~A}, h l \mathrm{~B}, i c a A, i c a \mathrm{D}, \mathrm{PEN}(\mathrm{S}), \mathrm{AMC}(\mathrm{S}), \mathrm{CFO}(\mathrm{S}), \mathrm{OXA}(\mathrm{S})$ and ERI(S) & 5 & $1,8 \%(1 / 55)$ \\
\hline$f b n \mathrm{~B}, h l \mathrm{~A}, h l \mathrm{~B}, i c a \mathrm{~A}, i c a \mathrm{D}, \mathrm{PEN}(\mathrm{R}), \mathrm{AMC}(\mathrm{S}), \mathrm{CFO}(\mathrm{S}), \mathrm{OXA}(\mathrm{S})$ and ERI(S) & 6 & $1,8 \%(1 / 55)$ \\
\hline$f b n \mathrm{~B}, h l \mathrm{~A}, h l \mathrm{~B}, i c a \mathrm{~A}, i c a \mathrm{D} . \mathrm{PEN}(\mathrm{R}), \mathrm{AMC}(\mathrm{S}), \mathrm{CFO}(\mathrm{S}), \mathrm{OXA}(\mathrm{S}), \mathrm{ERI}(\mathrm{S})$ and blaZ & 7 & $1,8 \%(1 / 55)$ \\
\hline$f b n B, h l \mathrm{~A}, h l \mathrm{~B}, i c a \mathrm{D}, \mathrm{PEN}(\mathrm{R}), \mathrm{AMC}(\mathrm{S}), \mathrm{CFO}(\mathrm{S}), \mathrm{OXA}(\mathrm{S})$ and ERI(S) & 8 & $3,6 \%(2 / 55)$ \\
\hline$f b n B, i c a \mathrm{D}, \mathrm{PEN}(\mathrm{R}), \mathrm{AMC}(\mathrm{S}), \mathrm{CFO}(\mathrm{S}), \mathrm{OXA}(\mathrm{S}), \mathrm{ERI}(\mathrm{S})$ and blaZ & 9 & $1,8 \%(1 / 55)$ \\
\hline$f b n A, c a p 8, h l \mathrm{~A}, h l \mathrm{~B}, i c a \mathrm{~A}, \mathrm{PEN}(\mathrm{R}), \mathrm{AMC}(\mathrm{S}), \mathrm{CFO}(\mathrm{S}), \mathrm{OXA}(\mathrm{S}), \mathrm{ERI}(\mathrm{S})$ and blaZ & 10 & $5,4 \%(3 / 55)$ \\
\hline$f b n A, h l \mathrm{~A}, h l \mathrm{~B}, i c a \mathrm{~A}, i c a \mathrm{D}, \mathrm{PEN}(\mathrm{R}), \mathrm{AMC}(\mathrm{S}), \mathrm{CFO}(\mathrm{S}), \mathrm{OXA}(\mathrm{S}), \mathrm{ERI}(\mathrm{S})$ and blaZ & 11 & $10,9 \%(6 / 55)$ \\
\hline$f b n A, h l \mathrm{~A} . h l \mathrm{~B}, i c a A, i c a \mathrm{D}, \mathrm{PEN}(\mathrm{R}), \mathrm{AMC}(\mathrm{S}), \mathrm{CFO}(\mathrm{S}), \mathrm{OXA}(\mathrm{S})$ and ERI(S) & 12 & $23,6 \%(13 / 55)$ \\
\hline$f b n A, h l \mathrm{~A} . h l \mathrm{~B} . i c a \mathrm{~A}, i c a \mathrm{D}, \mathrm{PEN}(\mathrm{S}), \mathrm{AMC}(\mathrm{S}) \mathrm{CFO}(\mathrm{S}), \mathrm{OXA}(\mathrm{S}), \mathrm{ERI}(\mathrm{S})$ and blaZ & 13 & $7,2 \%(4 / 55)$ \\
\hline$f b n A, h l \mathrm{~A}, h l \mathrm{~B}, i c a \mathrm{~A}, i c a \mathrm{D}, \mathrm{PEN}(\mathrm{S}), \mathrm{AMC}(\mathrm{S}), \mathrm{CFO}(\mathrm{S}), \mathrm{OXA}(\mathrm{S})$ and ERI(S) & 14 & $1,8 \%(1 / 55)$ \\
\hline$f b n A, h l \mathrm{~A}, h l \mathrm{~B}, i c a \mathrm{D}, \mathrm{PEN}(\mathrm{R}), \mathrm{AMC}(\mathrm{S}), \mathrm{CFO}(\mathrm{S}), \mathrm{OXA}(\mathrm{S}), \mathrm{ERI}(\mathrm{S})$ and blaZ & 15 & $5,4 \%(3 / 55)$ \\
\hline$f b n A, h l \mathrm{~A}, h l \mathrm{~B}, i c a \mathrm{D}, \mathrm{PEN}(\mathrm{R}), \mathrm{AMC}(\mathrm{S}), \mathrm{CFO}(\mathrm{S}), \mathrm{OXA}(\mathrm{S})$ and ERI(S) & 16 & $5,4 \%(3 / 55)$ \\
\hline$f b n A, h l \mathrm{~A}, h l \mathrm{~B}, i c a \mathrm{D}, \mathrm{PEN}(\mathrm{S}), \mathrm{AMC}(\mathrm{S}), \mathrm{CFO}(\mathrm{S}), \mathrm{OXA}(\mathrm{S})$ and ERI(S) & 17 & $1,8 \%(1 / 55)$ \\
\hline$f b n A, h l A, i c a \mathrm{D}, \mathrm{PEN}(\mathrm{R}), \mathrm{AMC}(\mathrm{S}), \mathrm{CFO}(\mathrm{S}), \mathrm{OXA}(\mathrm{S})$ and ERI(S) & 18 & $1,8 \%(1 / 55)$ \\
\hline$f b n A, h l A, i c a \mathrm{D}, \mathrm{PEN}(\mathrm{R}), \mathrm{AMC}(\mathrm{S}), \mathrm{CFO}(\mathrm{S}), \mathrm{OXA}(\mathrm{S}), \mathrm{ERI}(\mathrm{S})$ and blaZ & 19 & $1,8 \%(1 / 55)$ \\
\hline$h l \mathrm{~A}, h l \mathrm{~B}, i c a \mathrm{~A}, i c a \mathrm{D}, \mathrm{PEN}(\mathrm{R}), \mathrm{AMC}(\mathrm{S}), \mathrm{CFO}(\mathrm{S}), \mathrm{OXA}(\mathrm{S})$ and ERI(S) & 20 & $3,6 \%(2 / 55)$ \\
\hline$h l \mathrm{~A}, h \mathrm{~B}, \mathrm{PEN}(\mathrm{S}), \mathrm{AMC}(\mathrm{S}), \mathrm{CFO}(\mathrm{S}), \mathrm{OXA}(\mathrm{S}), \mathrm{ERI}(\mathrm{S})$ and blaZ & 21 & $1,8 \%(1 / 55)$ \\
\hline$h l \mathrm{~A}, h l \mathrm{~B}, \mathrm{PEN}(\mathrm{R}), \mathrm{AMC}(\mathrm{S}), \mathrm{CFO}(\mathrm{S}), \mathrm{OXA}(\mathrm{S})$ and ERI(S) & 22 & $1,8 \%(1 / 55)$ \\
\hline$h l \mathrm{~A}, h \mathrm{lB}, \mathrm{PEN}(\mathrm{R}), \mathrm{AMC}(\mathrm{S}), \mathrm{CFO}(\mathrm{S}), \mathrm{OXA}(\mathrm{S}), \mathrm{ERI}(\mathrm{S})$ and blaZ & 23 & $1,8 \%(1 / 55)$ \\
\hline
\end{tabular}

*S: susceptible and R: resistant

The genes responsible for production of capsular polysaccharide were also investigated. The cap8 gene was only detected in two strains whereas the unusual cap5 gene was not found. Occurrence of cap5 or cap8 genes varies in each geographic region. According to Tuchscherr et al. (2005), bacteria that do not express capsule induce chronic mastitis in mice, suggesting that the absence of capsule synthesis may help the bacteria to persist in the mammary glands. This idea was highly supported by the fact that the studied strains were obtained from cows presenting subclinical mastitis only detected by CMT and CCS.

The fibronectin binding proteins (FBN) A and B of $S$. aureus are multifunctional MSCRAMMs which recognize fibronectin, fibrinogen and elastin. FBN promotes internalization of $S$. aureus into epithelial and endothelial cells which are not normally phagocytic. Moreover, the promote evasion of immune responses and antibiotics. FBNA and FBNB are encoded by two closely linked but separately transcribed genes, $f b n \mathrm{~A}$ and $f b n \mathrm{~B}$ (Burke et al., 2010). Most of the strains in this study presented the $f b n \mathrm{~B}$ gene. These results are similar to those found by Kot et al. (2016) and are supported by reports that the gene $f b n \mathrm{~B}$ is more closely related with $S$. aureus isolates from subclinical mastitis and the absence of this gene may affect the ability to invade host cells. The adhesion to fibronectin is an important step in establishment of pathogenesis of the bovine mastitis (Kot et al.,2016).

The $\alpha$ - and $\beta$-haemolysins produced by $S$. aureus are pore-forming exotoxins that induce proinflammatory changes in mammalian cells, inactivate the immune system by their direct cytotoxic effect, and degrade tissues, providing bacteria with nutrients and facilitating spreading to new sites (Haveri et al., 2007). The $\alpha$-haemolysin, encoded by hla gene, has been suggested to be involved in peracute, gangrenous bovine mastitis. In this study, a high prevalence of both haemolysin genes, hla and hlb was observed, pointing to the bacterial potential for acute infection. Most of $S$. aureus from bovine mastitis produce $\alpha$ - and $\beta$-haemolysins. The high frequency of haemolysins genes show that these genes play an important role in pathogenesis of bovine mastitis. Previous studies report that hemolysin production may be unnecessary to cause mastitis, once strains that tested negative 
for both genes were detected in cattle affected by mastitis (Haveri et al., 2007).

Besides those virulence genes, this study also determined the agr typing, being the agrII type the most prevalent one. Melchior et al. (2009) suggested a better adaptation of agrII than agrI strains to dairy environment based on the higher prevalence of type II in bovine milk isolates.

The evaluation of antimicrobial resistance yielded a high prevalence of penicillin resistant strains confirming the common sensing that penicillin is rarely considered an option in treating Staphylococcus spp. infections. The indiscriminate use of penicillin to control and prevent infectious diseases in cattle without adequate control, leading to a series of consequences such as toxic effects, allergy problems and development of resistant strains Silva et al., 2012). In this study, 83.6\% (46/ 55) of the tested isolates were resistant to penicillin, similar to data reported from Silva et al. (2012), who found $95 \%$ of penicillin resistance in $S$. aureus from subclinical mastitis in Pernambuco, Brazil. Moreover, penicillin resistance of $S$. aureus has been associated with chronic mastitis due to the low cure rate of mastitis caused by $S$. aureus resistant to penicillins which makes these animals to be reservoirs of penicillin-resistant $S$. aureus causing the spread to other animals (Haveri et al., 2007). Silva et al. (2012) emphasizes the zoonotic risk of the presence of $S$. aureus strains resistant to penicillin from bovine mastitis due to the potential risk of transmission to humans of resistance in order to limit or prevent use for treatment.

Despite the high penicillin resistance detected, none of the strains tested positive for mecA gene, and only sixteen strains $(34.7 \%)$ presented blaZ gene in a scope of 46 strains. Detection of the mecA gene in isolates of bovine origin with oxacillin resistance phenotype is problematic. Melo et al. (2014) detected point mutations in the annealing region of primer, which resulted in design of new primers for the detection of mec gene in isolated bovine (mec bovine). GarciaAlvarez et al. (2011) also detected mutations in the gene mec, and described a new allele called $m e c \mathrm{C}$, this gene has been found in humans and animals, but until the present date, this allele was not detected in the Americas. These data point to the need of studies about the underlying mechanism of the observed penicillin resistance.

\section{CONCLUSION}

The spread of $S$. aureus in dairy herds is of concern not only because of its ability to cause the mammary gland infection due to its virulence potential but also considering how difficult it is to create effective preventive measures. This study has concluded that penicillin is not an antimicrobial choice for $S$. aureus infection treatment and it must be banished from dairy environment.

\section{REFERENCES}

ATKIN, K.E.; MACDONALD, S.J.; BRENTNALL, A.S. et al. A different path: revealing the function of staphylococcal proteins in biofilm formation. FEBS Letters, v.588, p.1869-1872, 2014.

AUNG, M.S.; URUSHIBARA, N.; KAWAGUCHIYA, M. et al. Virulence factors and genetic characteristics of methicillin-resistant and methicillin-susceptible Staphylococcus aureus isolates in myanmar. Microb. Drug Resist., v.17, p.525-535, 2011.

BOWNIK, A.; SIWICKI, A. Effects of staphylococcal hemolysins on the immune system of vertebrates. Cent. Eur. J. Immunol., v.33, p.87, 2008.

BUR, S.; PREISSNER, K.T.; HERRMANN, M.; BISCHOFF, M. The Staphylococcus aureus extracellular adherence protein promotes bacterial internalization by keratinocytes independent of fibronectin-binding proteins. $J$. Invest. Dermatol., v.133, p.2004-2012, 2013.

BURKE, F.M.; MCCORMACK, N.; RINDI, S. et al. Fibronectin-binding protein $\mathrm{B}$ variation in Staphylococcus aureus. BMC Microbiol., v.10, p.1, 2010.

BUZZOLA F.R.; ALVAREZ L.P.; TUCHSCHERR L.P. et al. Differential abilities of capsulated and noncapsulated Staphylococcus aureus isolates from diverse agr groups to invade mammary epithelial cells. Infect. Immun., v.75, p.886-891, 2007. 
CAPURRO, A.; ASPÁN, A.; UNNERSTAD, H.E. et al. Identification of potential sources of Staphylococcus aureus in herds with mastitis problems. J. Dairy Sci., v.93, p.180-191, 2010.

CASSOL, D.M.S.; SANDOVAL, G.; PERÍCOLE, J. Mastite bovina. Hora Vet., v.29, p.27-31, 2010.

CIFTCI， A.; FINDIK, A.; ONUK, E.E.; SAVASAN, S. Detection of methicillin resistance and slime factor production of Staphylococcus aureus in bovine mastitis. Braz. J. Microbiol., v.40, p.254-261, 2009.

CLINICAL Performance Standards for Antimicrobial Disk and Diluition Susceptibility Tests for Bacteria Isolated From Animals; Approved Standards. 4ed. Wayne: Clinical and Laboratory Standards Institute, 2013. (Document VET01-A4).

EL-SAYED, A.; ALBER, J.; LAMMER, C. et al. Comparative study on genotypic properties of Staphylococcus aureus isolated from clinical and subclinical mastitis in Mexico. Vet. Méx., v.37, p. 165-179, 2006.

GARCÍA-ÁLVAREZ, L.; HOLDEN, M.T.; LINDSAY, H. et al. Meticillin-resistant Staphylococcus aureus with a novel mecA homologue in human and bovine populations in the UK and Denmark: a descriptive study. Lancet Infect. Dis., v.11, p.595-603, 2011.

HAVERI, M.; HOVINEN, M.; ROSLÖF, A.; PYÖRÄLÄ, S. Molecular types and genetic profiles of Staphylococcus aureus strains isolated from bovine intramammary infections and extramammary sites. J. Clin. Microbiol, v.46, p.3728-3735, 2008.

HAVERI, M.; ROSLÖF, A.; RANTALA, L.; PYÖRÄLÄ, S. Virulence genes of bovine Staphylococcus aureus from persistent and nonpersistent intramammary infections with different clinical characteristics. J. Appl. Microbiol., v.103, p.993-1000, 2007.

HOOKEY, J.V.; RICHARDSON, J.F.; COOKSON, B.D. Molecular typing of Staphylococcus aureus based on PCR restriction fragment length polymorphism and DNA sequence analysis of the coagulase gene. J. Clin. Microbiol, v.36, p.1083-1089, 1998.
KOT, B.; SZWEDA, P.; FRANKOWSKAMACIEJEWSKA, A. et al. Virulence gene profiles in Staphylococcus aureus isolated from cows with subclinical mastitis in eastern Poland. J. Dairy Res., v.2, p.228-235, 2016.

MELCHIOR M.B.; VAN OSCH M.H.J.; GRAAT R.M. et al. Biofilm formation and genotyping of $S$. aureus bovine mastitis isolates: evidence for lack of penicillin-resistance in Agrtype II strains. Vet. Microbiol., v.137 p.83-89, 2009.

MELO, D.A.; COELHO, I.S.; MOTTA, C.C. et al. Impairments of mecA gene detection in bovine Staphylococcus spp. Braz. J. Microbiol., v.45, p.1075-1082, 2014.

MOODLEY, A.; STEGGER, M.; BAGCIGIL, A.F. et al. spa typing of methicillin-resistant Staphylococcus aureus isolated from domestic animals and veterinary staff in the UK and Ireland. J. Antimicrob. Chemother., v.58, p.11181123, 2006.

MURAKAMI, K.W.; MINAMIDE, K.; WADA, W. et al. Identification of methicillin resistant strains of staphylococci by polymerase chain reaction. J. Clin. Microbiol., v.29, p.2240-2244, 1991.

NILSSON, I.M.; HARTFORD, O.; FOSTER, T.; TARKOWSKI, A. Alpha-toxin and gamma-toxin jointly promote Staphylococcus aureus virulence in murine septic arthritis. Infect. Immun., v.67, p.1045-1049, 1999.

OTE, I.; TAMINIAU, B.; DUPREZ, J.N. et al. Genotypic characterization by polymerase chain reaction of Staphylococcus aureus isolates associated with bovine mastitis. Vet. Microbiol., v.153, p.285-292, 2011.

RESHI, A.A.; HUSAIN, I.; BHAT, S.A. et al. Bovine mastitis as an evolving disease and its impact on the dairy industry. Int. J. Cur. Res. Rev., v.7, p.48, 2015.

RIGOLIN-SÁ, O.; FRANÇA, N.; ESPER, K.C.P.; ANDRADE, D.P. Quality of raw refrigerated milk based on $\mathrm{SCC}$ and $\mathrm{TBC}$ indicators in the Southwest of Minas Gerais state, Brazil. Rev. Inst. Laticínios Cândido Tostes, v.69, p.348-356, 2014. 
ROSATO, A.E.; KREISWIRTH, B.N.; GRAIG, W.A. et al. mecA-BlaZ corepressors in clinical Staphylococcus aureus isolates. Antimicrob. Agents Chemother., v.47, p.1463-1466, 2003.

SHOPSIN, B.; MATHEMA, B.; ALCABES, P. et al. Prevalence of agr specificity groups among Staphylococcus aureus strains colonizing children and their guardians. J. Clin. Microbiol., v.41, p.456-459, 2003.

SILVA, E.R.; PEREIRA; A.G.; MORAES, W. et al. Perfil de sensibilidade antimicrobiana in vitro de Staphylococcus aureus isolado de mastite subclínica bovina. Rev. Bras. Saúde Prod. Anim., v.13, p.701-711, 2012.

TUCHSCHERR, L.P.; BUZZOLA, F.R.; ALVAREZ, L.P. et al. Capsule-negative Staphylococcus aureus induces chronic experimental mastitis in mice. Infect. Immun., v.73, p.7932-7937, 2005.
VASUDEVAN P.; NAIR M.K.M.; ANNAMALAI T.; VENKITANARAYANA K.S. Phenotypic and genotipic characterization of bovine mastitis isolates $S$. aureus for biofilm formation. Vet. Microbiol., v.92, p.179-185, 2003.

WANG, D.; WANG, Z.; YAN, Z. et al. Bovine mastitis Staphylococcus aureus: antibiotic susceptibility profile, resistance genes and molecular typing of methicillin-resistant and methicillin-sensitive strains in China. Infect. Genet. Evol., v.31, p.9-16, 2015. 